\title{
Common auditors and cross-country M\&A transactions
}

\author{
Justin Chircop \\ Lancaster University Management School \\ Lancaster University, Lancaster, UK \\ Tel: +44 (0)1524 594634 \\ j.chircop1@lancaster.ac.uk
Sofia Johan*
York University - Schulich School of Business
4700 Keele Street, Toronto,
Ontario M3J 1P3, Canada
sjohan@schulich.yorku.ca \\ Monika Tarsalewska \\ University of Exeter Business School \\ XFI building, Streatham Campus, \\ Rennes Drive, Exeter EX4 4ST, UK \\ m.tarsalewska@exeter.ac.uk
}

January 2017

*Corresponding author. We thank Giancarlo Giudici (discussant) and conference participants at the CFA-FRL-JIFMIM-Schulich Conference on Developments in Financial Institutions, Governance and Misconduct held in Toronto, Canada for their comments and suggestions. All errors are our own. 


\title{
Common auditors and cross-country M\&A transactions
}

\begin{abstract}
Using a comprehensive sample of cross-country mergers and acquisitions for the period 2000 to 2014 we examine the effect of common auditors on the efficiency of cross-country M\&A transactions. We predict that the use of common auditors reduces uncertainty, resulting in higher M\&A efficiency. We find that this common-auditor effect results in a positive market reaction to the M\&A announcement, lower premium and greater increase in return on assets following the M\&A transaction. Further, we find that these effects are more pronounced the greater the M\&A transaction uncertainty and when the accounting standards of the transacting parties differ.
\end{abstract}

Keywords: Auditors; Information transfer; M\&As

JEL Classification: D82; D83; M41 


\section{Introduction}

Cross-country M\&A transactions arguably create more information asymmetry than within country M\&A transactions. This occurs not only due to the geographic distance between parties but also as the parties to the transaction are operating in different cultural, legal and economic environments (Rossi and Volpin, 2004). For both within-country and cross-country M\&A's, a significant amount of information is required to mitigate traditional financial risk and determine return optimization. Such information consists of codified or explicit information such as balance sheets or performance records, and more tacit information that is context dependent and personal (Polanyi, 1966; Arrow 1962; and Von Hippel 1994). In comparison to codified information, tacit information is harder to formalize and transmit over distance, necessitating more interpersonal interaction among parties; somewhat of a challenge for parties to cross country M\&As. The codified information however is easily transmittable using a standardized formal and more empirical method.

In this study we seek to determine whether the transfer of codified information through the use of a common audit network for cross-country M\&As could result in more efficient transactions. We do this by referring to the suggestion in the existing literature that common auditors to the target and acquirer firms can reduce uncertainty and mitigate the negative effects of information asymmetry in within-country M\&A transactions (Cai at al., 2016). Whether common auditors are important in cross-country M\&A transactions has, to our knowledge, never been studied.

In cross-country M\&A transactions, the dispersion of auditors, caused by the same geographical, language and cultural barriers faced by the transacting parties, makes it more difficult for auditors to act as information intermediaries. Due to differing cultural norms and 
potential language barriers, even when the parties to the transaction are audited by similarly qualified auditors, it is likely that such audit firms operate independently of each other due to differing accounting standards, thus not only effectively sharing limited amounts of information but potentially increasing the already significant information asymmetry. It is therefore an empirical question if when the parties to the transaction are audited by a common audit network, which hereof we refer to as common auditors, the common auditor effect documented by Cai et al. (2016) for within-country M\&A transactions still applies.

To test whether common auditors are associated with higher quality cross-country M\&A transactions we identify all completed cross-country M\&A transactions, for the period 2000 to 2014, in which the acquirer owned less than 50\% of the target prior to the purchase and acquired full ownership of the target in the M\&A transaction. As we need stock market data for some of our tests, we require both the acquirer and the target to be publicly traded. After eliminating deals with missing data our final sample consists of 351 deals, where 62 are common auditor deals and 289 are non-common auditor deals.

Similar to prior studies (e.g. Asquith et al., 1983; Bradley et al., 1988; Cai and Sevilir, 2012; Agrawal et al., 2013; Goodman et al., 2014; Cai et al., 2016) we use acquisition announcement returns as our main measure of M\&A quality and expect common auditors to be associated with higher acquisition announcement returns. Subsequently, we test whether other proxies used in prior literature to capture M\&A quality, give us similar results. Specifically, we test whether common auditors affect premium and change in return on assets. We expect the acquirer to pay a lower premium in high quality M\&A transactions, and the use of common auditors to be associated with an increase in return on assets following the M\&A deal. In line with our expectations, we find that common auditors are associated with higher acquisition 
announcement returns, lower premium and a larger change in performance following the M\&A transaction.

Further, we test whether the common auditor effect is more pronounced in cross-country M\&A transactions with greater uncertainty. The greater the uncertainty, the more likely that the parties will benefit from standardized information. Specifically, we test whether such effect is stronger when the target is smaller, operates in the high-tech industry and has higher growth. We also determine if the use of common auditors among transactions using different accounting standards to those of the acquirer will result in better deals. In line with our expectations, we find that the common auditor effect is in fact stronger when the M\&A transactions present greater uncertainty and when the accounting standards of parties differ.

Our cross-country analyses would not be complete without taking into account the differences in cultural values across deals. We find, after taking into account two separate cultural measures (the World Value Survey and the Hofstede Indices) that the use of common auditors results in better quality deals. Finally, we test for the potential common auditor effect on the acquirer and find that the use of common auditors creates value to the acquirer.

Collectively these results point to the common auditor effect documented in Cai et al. (2016) holding also in cross-country M\&A transactions, where even though the need for information intermediaries is higher, there is less opportunity for information transfer. In interpreting these results caution should be exercised in that the quantity of information exchanged between auditors is unobservable and thus we cannot directly speak to the type, amount, and the transfer mechanics of such information. We are also unable to observe when such transfer of information is carried out. The transfer of information between auditors can take place at any point during the M\&A process. Early on in the M\&A transaction, the transfer of 
information between common auditors can facilitate the identification of a target. Subsequently, information sharing may facilitate the acquirer pricing of the target, structuring of the M\&A deal and the valuation of synergies arising from the M\&A transaction. Finally, common auditors may facilitate the integration of the target firm within the merged company. Our findings do suggest however that the use of common auditors in M\&As may benefit parties as a result of better access to codified or explicit information such as balance sheets or performance records that are standardized, thus enabling parties to better mitigate financial risk and determine return optimization.

Our study makes some important contributions. First, we add to prior literature examining the role of auditors in M\&A transactions. Most prior literature has examined the role of auditors in M\&A transactions separately. For example, Xie et al. (2013) find that targets audited by Big 4 firms are more likely to be acquired, while Golubov et al. (2012) find that targets with Big 4 firms have higher synergy and acquirer announcement returns. Recently, two studies have analyzed the effect of common auditors in within-country M\&A transactions. Dhaliwal et al. (2016, p.1) find that common auditors are found in nearly a quarter of the deals and that targets are more likely to receive a bid from a firm having the same auditor. Moreover, they find that shared auditors "are associated with significantly lower deal premiums, lower target event returns, higher event returns and higher deal completion rates”. In a similar vein, Cai et al. (2016) find that shared auditors act as information intermediaries and give rise to higher quality M\&A transactions. We add to this within-country literature by showing that common auditors also play an economically significant role in cross-country audits, when significant barriers to the transfer of both tacit and codified information between target and acquirer auditors exist. 
Second, we add to the literature examining the effect of sharing a common agent on economic outcomes. Particularly related to our study, Agrawal et al. (2013) studies the role of common investment banks in M\&A transactions and shows that acquirers benefit more than targets from such transactions. Similarly, Cai and Sevilir (2012) find that board connections between the target and the acquirer favor the acquirer and that such benefit depends on the type

of board connection. Related to this literature are Dhaliwal et al. (2016) and Cai et al. (2016), which as discussed previously show that common auditors have an economically significant effect on M\&A transactions. A common trait of these studies is that all relate to within-country M\&A transactions. We add to this literature by exploring the effect of common auditors in crosscountry M\&A transactions, where language, legal, and cultural norms will differ.

The paper proceeds as follows. In Section 2, we discuss prior literature related to M\&As, with particular emphasis on literature which studies the role of common auditors on M\&A transactions. Section 3 sets out the sample selection process and discusses the research design while Sections 4 and 5 discuss the main results and additional analyses respectively. Section 6 concludes.

\section{Literature review and hypotheses development}

An acquisition is one of the major investments a firm undertakes. When two firms come together synergies are created. Yet, the pre-M\&A evaluation of synergies is often a non-trivial task that is largely based on publicly available information. Usually, the acquirer performs a due diligence investigation that enables it to estimate the intrinsic value of the target. The first part of this process is to gather publicly available information that allows the acquirer to set the basic assumptions behind the pricing negotiations and estimate potential synergies that will later on 
have an effect on the efficiency of the deal and its performance (Wangerin, 2016). The information provided has crucial implications on the valuation judgments and the process is called the preliminary due diligence. Second, the acquirer signs the confidentiality agreement and starts the due diligence review. The confidentiality agreement grants the acquirer access to private information that might include management reports, financial forecasts, or information on planned investments. Both parties commit to negotiate the deal. Finally, the acquirer performs a transactional due diligence to verify the accuracy of the target's financial information and can withdraw the offer or complete the deal (Bruner 2004, Skaife and Wangerin, 2013).

As evident from above, the information asymmetry between the acquirer and the target firms in an M\&A transaction represents a high degree of uncertainty. This uncertainty is even greater in cross-country $M \& A$ transactions where uncertainties relating to the valuation of the target and the potential synergies arising from the transaction are compounded by differences in the cultural, legal and financial environments under which the two companies operate. Prior research indicates that such uncertainty negatively effects M\&A quality, as evident from lower acquirer announcement returns and post-acquisition performance (McNichols and Stubben, 2015; Erickson et al., 2012). Moreover, Martin and Shalev (2016) find that more firm specific target information alleviates uncertainty and improves acquirer announcement returns and the expected value of the synergies arising from the M\&A transaction.

In complex deals or where the acquirer lacks prior M\&A experience, investment bankers are usually appointed (Servaes and Zenner, 1996) to alleviate M\&A uncertainty by providing acquirers with advise on target valuation, deal price and structure (Goodman et al., 2014). In a similar vein and more related to our study, Agrawal et al. (2013) and Cai and Sevilir (2012) show that shared investment advisors and interlocked directors significantly influence M\&A 
quality by reducing information asymmetry in the M\&A transaction. In a recent study Cai et al. (2016) find that the use of common auditors reduces this information asymmetry between the acquirer and the target, ultimately resulting in higher quality M\&A transactions. Moreover, in a concurrent study Dhaliwal et al. (2016) finds that the benefits of this common audit effect accrue to the acquirer at the expense of the target.

A common research design choice of the above studies analyzing the common auditor effect is that such effect is studied within U.S. M\&A transactions. In our study we seek to extend this analysis to a cross-country setting. In such a setting even though there might be greater uncertainty in the M\&A transaction and thus a greater need to share information, country specific differences between the target and the acquirer countries pose additional obstacles to the sharing of information between common auditors. Specifically, it is likely that direct discussions between common auditors about the M\&A transaction, which Cai et al. (2016) identifies as the primary information channel through which information between common auditors is shared, is hampered by cultural, legal and language barriers. Given this, it is likely that in a cross-country setting, the channel through which information is shared between common auditors is through financial statement comparability. As discussed by Francis et al. (2014) and Blacconiere et al. (2011) each firm has a unique style of interpreting accounting rules, and thus it is likely that firms within the same audit firm network are better able to understand and interpret accounting rule choices.

As we mentioned earlier, the tacit information utilized to determine target valuation, deal price, and structure, in comparison to the arguably more codified financial statements, is harder to formalize and transmit over distance. We note however that the sharing of information in network audit firms is facilitated through developments in information technology (IT). IT 
structures such as the use of the intranet, database management systems and group support systems enables the efficient and effective capturing and sharing of information and knowledge throughout the networked firms (Banker et al., 2002; Winograd et al., 2000). Such systems do not only provide network firms with access to third party expertise but also provide network firms with the ability to share audit team research, such as up-to-date interpretation of accounting rules, processes and working papers. Such an infrastructure enhances access to important, up-todate material which should improve efficiency and reduce the information asymmetry inherent in M\&A transactions. More importantly such systems "enable auditors to work in 'virtual teams' that are not bound by time and distance constraints" (Vera-Munoz et al., 2006 p.139).

In conclusion while it has been established that in a single country setting, the U.S., common auditors increase M\&A quality (Cai et al., 2016), it is an empirical question as to whether such a common auditor effect holds in a cross-country setting where cultural, legal and language differences may hamper the transfer of information between common auditors. Therefore, in this study we seek to contribute to Cai et al. (2016 p.79) call for "future research to further examine the various aspects and consequences of a common auditor in M\&A transactions".

\section{Sample selection and research design}

\subsection{Research design}

In this section we discuss the research design. Our main prediction is that cross-country deals where firms have the same auditor should improve M\&A transaction quality. We therefore estimate the following model using an ordinary least squares (OLS) regression: 


$$
\begin{gathered}
\text { SYNERGY }= \\
\alpha+\text { SAME_AUDITOR + DEAL_CONTROLS }+ \text { TRG_CONTROLS + ACQ_CONTROLS + } \\
\text { COUNRY_CONTROLS + FIXED_EFFECTS }+\varepsilon
\end{gathered}
$$

where SYNERGY is the sum of the weighted 10-day acquirer and target cumulative abnormal return starting five days before and ending five days after the M\&A announcement date, calculated using the adjusted return or market model. Our main independent variable is $S A M E \_A U D I T O R$ that is an indicator variable equal to one if the acquirer and the target share a common auditor, and zero otherwise. We also include several control variables commonly used in prior literature that proxy for deal, firm, and country characteristics. We also include year and industry fixed effects to control for any time trend and industry specific effects. Standard errors are clustered by year and industry. All variables are defined in Appendix 1.

\subsection{Sample selection}

We obtain a sample of cross-country mergers and acquisitions from Thomson Reuters Securities Data Company (SDC) database from 2000 to 2014. We start from year 2000 as the data on auditors is not complete prior to that year. The sample selection procedure for the analysis is as follows. First, we identify all completed cross-country transactions in which the acquirer owned less than $50 \%$ of the target prior to the purchase and acquired $100 \%$ of the target. In other words, similar to other studies we only include the transactions where there was an unequivocal change in control (Moeller et al., 2004; McNichols and Stubben, 2015). Subsequently, as we require stock price data for both parties to the transaction we drop deals where either the target or the acquirer is not a publicly traded firm. Finally, we collect 
information on the auditors of the sampled firms from Thomson Reuters, and accounting and market data from Worldscope and Datastream respectively.

In table 1 we present the distribution of observations over the sample period. After eliminating deals with missing data we end with a final sample of 351 deals, where 62 are common auditor deals and 289 are non-common auditor deals. The data are spread over the sample period with the highest frequency of deals in 2012 (13.39\%).

[Please insert table 1 here]

In table 2 we present descriptive statistics for the full sample of cross-country deals (in column 1 and 2), deals with common auditor (in column 3 and 4), and deals with non-common auditor (in column 5 and 6). In the last two columns we present the difference in means and the ttest for difference in means.

First, we present the descriptive statistics for the M\&A efficiency measure SYNERGY. Our main dependent variable is SYNERGY[-5;5] that is the sum of the weighted 10 day acquirer and target cumulative abnormal return around the M\&A announcement date, calculated using the adjusted return. We also, present results for different return window length i.e. SYNERGY [10;10] and SYNERGY [-20;20] that are calculated using sum of the weighted 20 and 40 day acquirer and target cumulative abnormal return around the M\&A announcement date, respectively.

In these univariate tests we find a positive difference in means between common-auditor and non-common auditor deals. ${ }^{1}$ This confirms our earlier expectations that the synergies are

\footnotetext{
${ }^{1}$ This difference is statistically significant for the lengthiest time window.
} 
higher when the target and the acquirer share a common auditor. Second, we present descriptive statistics for control variables. We only find small differences between the control variable means for the two groups of M\&A transactions. The differences between common auditor and non-common auditor deals are only statistically significant for TRG_ASSETS, where we find that common auditor deals have significantly larger targets, and $T R G_{-} M B$, where we find that common auditor deals have targets with larger market-to-book values.

[Please insert table 2 here]

In table 3 we present correlations among our variables. ${ }^{2}$ SYNERGY is positively correlated with SAME_AUDITOR suggesting that common auditors do increase the efficiency of cross-country M\&As. We also find a significant positive correlation between SYNERGY and $T R G \_L E V E R A G E, T R G \_M B$ and $A C Q \_M B$ and a significant negative correlation between SYNERGY and ACQ_ASSETS. These results suggest that SYNERGY is correlated with the M\&A transaction parties' growth opportunities. In line with our results in table 2, we find a statistically significant positive correlation between SAME_AUDITOR and TRG_ASSETS.

[Please insert table 3 here]

\section{Main Results}

\subsection{Common auditors in cross-country deals and $M \& A$ synergies}

\footnotetext{
${ }^{2}$ In table 3 we do not show correlations with country characteristics to conserve space. These are available from the authors upon request.
} 
We show the main results for our base model in table 4 where the main dependent variable is SYNERGY. In Model 1 we present the results when we calculate synergies based on adjusted return. In Model 2 we present the results when we calculate synergies based on the market model. For the market model, we use 200 daily returns starting from 242 days before the announcement date to 43 days before the announcement date, and we require at least 50 daily returns available for each firm. SYNERGY is estimated as the portfolio cumulative abnormal return from five days before to five days after the announcement date, where the portfolio is the market value weighted portfolio of both the acquirer and target firms.

The effect of a common auditor on synergy is positive and significant irrespective of which method we use to calculate abnormal returns. We find that having common-auditors increases synergies based on adjusted returns by $1.8 \%$ and increases synergies based on the market model by $4.9 \%$. Both results are statistically significant at $1 \%$ level of significance. The coefficients on the control variables are consistent with prior literature. For example, we observe that acquirer size is negatively associated with SYNERGY (Kimbrough and Louis, 2011; Golubov et al., 2012;Cai et al., 2016); highly stock financed deals give rise to lower syngergies (Louis, 2005; Cai et al., 2016); and that tender offers give rise to larger market returns (Golubov et al., 2012; Cai and Sevilir, 2012). The magnitude of the coefficients for these variables suggest that synergies based on adjusted returns (market model) increase by $1 \%(1.8 \%)$ when stucturing an M\&A deal as a tender increases; and decrese by $5.2 \%(7 \%)$ when the deal is financed by stock. Further, synergies based on adjusted returns (market model) decrease by $2.7 \%(3.3 \%)$ when there is a unit increase in $A C Q \_A S S E T S$.

[Please insert table 4 here] 


\subsection{Common auditors in cross-country deals and target characteristics}

In this subsection we examine the effect of common auditors on M\&A synergies conditioned on certain target characteristics that proxy for information asymmetry, industry complexity, and growth. We predict that in the presence of greater M\&A information asymmetry we should observe a stronger relationship between common auditors and M\&A efficiency. We assume that the smaller the target firm the less information is available on its operations and thus the harder it is for the acquirer to accurately measure the expected synergies. Thus, we expect that common auditors are particularly helpful when the transaction involves a small target firm. As we measure the target information asymmetry as the inverse of the target's assets, we expect a positive coefficient on an interaction term between inverse of the target's assets and the indicator variable for common auditors. In table 5 we present univariate and multivariate tests in columns 1 and 2, respectively. The significiant and positive coefficient on the interaction term, $I N V \_T R G \_A S S E T S * S A M E \_A U D I T O R$, suggests that when targets are small the presence of common auditors is incrementally positively related to SYNERGY.

[Please insert table 5 here]

Subsequently, we expect that when a target operates in an industry that is highly technologically advanced the common auditor effect is greater. Following Loughran and Ritter (2004), we define the high-tech industry as an indicator variable equal to one if the target is from a high-tech industry, and zero otherwise. ${ }^{3}$ We focus on high-tech targets since such companies

\footnotetext{
${ }^{3}$ According to Loughran and Ritter (2004) "Tech stocks are defined as those in SIC codes 3571, 3572, 3575, 3577, 3578 (computer hardware), 3661, 3663, 3669 (communications equipment), 3671, 3672, 3674, 3675, 3677, 3678,
} 
potentially pose greater uncertainty to the acquirer. Also, they might affect synergies and postacquisition performance due to the embedded complexity when integrating their operations with those of the acquirer firm. In table 6 we present the results for the univariate and multivariate tests in columns 1 and 2 respectively. The presence of common auditors in deals involving hightech targets generates significantly higher deal synergies when compared to non-common auditor deals involving high-tech targets, as evidenced by the significant and a positive coefficient on the interaction term.

[Please insert table 6 here]

Acquiring targets with growth potential is a common growth strategy and an important motivation for acquisitions (Levine, 2013). Yet, it is difficult to estimate the true growth potential of a target company. Common auditors likely facilitate the assessment of target growth potential and are possibly better able to help the acquirer exploit the targets' growth opportunities. Therefore, we predict that common-auditors are particularly important when it comes to the acquisition of target firms with growth potential. In table 7 we report the results when we interact common-auditor with a proxy for targets growth potential i.e. market-to-book value. We find that the incremental effect is positive and significant at the $1 \%$ level. It suggests that in transactions where the target has growth potential the positive common auditor effect on synergy is significantly stronger.

[Please insert table 7 here]

3679 (electronics), 3812 (navigation equipment), 3823, 3825, 3826, 3827, 3829 (measuring and controlling devices), 3841, 3845 (medical instruments), 4812, 4813 (telephone equipment), 4899 (communications services), and 7371, $7372,7373,7374,7375,7378$, and 7379 (software).” 


\subsection{Different accounting standards}

Given the properties of our cross-country sample of M\&As we can exploit differences in accounting standards between the target and the acquirer. We are interested if common auditors facilitate the information flow and affect merger synergies in M\&A transactions where the target and acquirer have different (local) accounting standards.

We hand collect the data on when the International Financial Reporting Standards (IFRS) were introduced in each country in our sample. ${ }^{4}$ We define the variable $D I F F_{-} A C C_{-} S T D$ as an indicator variable that takes the value one if the acquirer and the target have different local accounting standards, and zero if both had adopted IFRS.

We expect instances where the target and the acquirer use different accounting standards to result in greater difficulty for one party to understand the financial statements of the other party. This difficulty makes estimating the potential valuation and synergies from the deal more challenging. In this ambit, common auditors in their role as information intermediaries mitigate these challenges. In order to test this prediction, we interact the variable SAME_AUDITOR with DIFF_ACC_STD. We present the results of this analysis in table 8. We find that the interaction effect has a positive and significant effect, at the 5\% level, on M\&A synergies. This suggests that the presence of common auditors in M\&A deals involving parties using different accounting standards is associated with higher M\&A quality.

[Please insert table 8 here]

\section{Further analyses}

\footnotetext{
${ }^{4}$ Data are publicly available at: www.ifrs.org.
} 
While our primary measure of M\&A efficiency is synergies, in section 5.1 and 5.2 we look at other measures of M\&A deal efficiency that have been used in prior studies (e.g. Dhaliwal et al., 2016), specifically deal premium and deal performance. Finally, in section 5.3 we test whether our main results hold when we control for cultural differences between the acquirer and target firms; while in section 5.4 we test for the common auditor effect of acquirer abnormal returns.

\subsection{Common auditors in cross-country deals and deal premium}

In this subsection we examine the effect of common auditors on deal premium in crosscountry transactions. We estimate the following model:

PREMIUM $=\propto$

+SAME_AUDITOR + DEAL_CONTROLS + TRG_CONTROLS + ACQ_CONTROLS + COUNRY_CONTROLS + FIXED_EFFECTS $+\varepsilon$

where PREMIUM is measured as the difference between the price offered in the bid and the target's trading price four weeks prior to the announcement. Given that Officer (2003) suggests the interpretation of large and negative premiums is difficult, we delete observations with premiums in excess of $150 \%$ or less than $0 \%$.

In line with the previously discussed findings, the results shown in table 9 indicate a positive common auditor effect on M\&A deals. Specifically, we find that the effect of same auditor on deal premium is negative and significant, as evidenced by the negative coefficient on SAME_AUDITOR.. This result suggests that acquirers are less likely to overpay in M\&A deals involving common auditors. The results for the control results are similar to prior analyses. 
[Please insert table 9 here]

\subsection{Common auditors in cross-country deals and deal performance}

In this subsection we examine in a cross-country setting the effect of common auditors on deal performance proxied by an accounting based measure. We estimate the following model:

$$
\begin{gathered}
\text { CHG_ROA }=\propto \\
+ \text { SAME_AUDITOR }+ \text { DEAL_CONTROLS }+ \text { TRG_CONTROLS + ACQ_CONTROLS + } \\
\text { COUNRY_CONTROLS }+ \text { FIXED_EFFECTS }+\varepsilon
\end{gathered}
$$

where $C H G_{-} R O A$ is defined as the difference between the one-year average ROA of the combined firm after the acquisition and one-year weighted-average ROA of the acquirer and the target before the acquisition. ROA is measured as operating income before depreciation at year $t$ scaled by average of year $t$ and year $t-1$ total assets.

In table 10 we present the results for Eq.3. We show that the effect of same auditor on the change in return on assets is positive and significant at the $1 \%$ level of significance. This result suggests that having common auditors in cross-country M\&A deals increase the change in ROA by $13 \%$ when compared to non-common auditor deals. Further, we find that a one unit increase (decrease) in $A C Q \_A S S E T S$ (TRG_ASSETS) increase $C H G \_R O A$ by $6.9 \%$ (4.3\%) respectively.

[Please insert table 10 here] 


\subsection{Common auditors in cross-country deals and cultural differences}

To ensure that our results are not driven by cultural differences/similarity between the countries in which the parties to the transaction are based, in this subsection we study the effect of common auditors when controlling for cultural differences. Given that there is no single measure of 'cultural' similarities/differences we first proxy such differences using data from the World Value Survey as used by Ahern et al. (2015), and secondly we use the commonly used Hofsted cultural indices (Datta and Puia, 2015; and Hain et al., 2015). For this analyses, we use synergy based on adjusted returns, SYNERGY [-5;5] as our dependent variable.

We present the results for this analysis in table 11. First, in Model 1 we control for the logarithmic transformation of the absolute differences between the parties to the M\&A transactions in two cultural values that are taken from World Values Survey (WVS): 1) TRUST where respondents in a particular country were asked to answer the following question: "Generally speaking, would you say that most people can be trusted or that you need to be very careful in dealing with people?"; and 2) INDIVIDUALISM were respondents in a particular country were asked to answer the following question: "How would you place your views on this scale?"

Second, in Model 2 of table 11 we include the logarithmic transformation of the absolute difference between the parties to the M\&A transaction for several cultural values of Hofstede Index (Hofstede and Bond, 1984; and Hofsetde et al.. 2010) such as PDI (Power Distance Index), IDV (Individualism vs. Collectivism), MAS (Masculinity vs. Femininity), UAI (Uncertainty Avoidance Index), LTOWVS (Long-term Orientation vs. Short-term Orientation), and $I V R$ (Indulgence vs. Restraint). 
In both analyses we find that our previously discussed results are robust to the inclusion of the additional controls. Specifically, the variable SAME_AUDITOR is still positive and significant at $1 \%$ level in both analyses. We also find that among the cultural dimensions analyzed, the Power Distance Index and Uncertainty Avoidance Index seem to play important roles in our analyses, where a one-unit increase (decrease) in our measure of power distance (uncertainty avoidance) increases SYNERGY by $2.9 \%(1.9 \%)$.

\section{[Please insert table 11 here]}

\subsection{Common auditors in cross-country deals and acquirer value}

In table 12, we show the results of the regression analysis where we substitue SYNERGY with $A C Q \_C A R$ as our dependent variable. $A C Q \_C A R[-5 ; 5]$ is the 10 -day acquirer cumulative abnormal return around the M\&A announcement date. The results in Model 1 show a significant and positive association between $C O M M O N \_A U D I T O R$ and $A C Q \_C A R$ suggesting that the presence of common auditors increases cumulative abnormal acquirer returns around the M\&A announcement date. The result is significant at the $1 \%$ level and suggests a postive common auditor effect of $2.1 \%$ on $A C Q \_C A R$. In model 2, we control for acquirer overpayment

(PREMIUM) and find that our inference hold albeit the relationship between COMMON_AUDITOR and ACQ_CAR is weaker.

[Please insert table 12 here]

\section{Conclusion}


In this paper, we study whether the presence of common auditors in cross-country M\&A transactions increases the quality of the deal. Cross-country M\&A transactions present significant uncertainties to the parties of the transaction as the tacit information required to determine target valuation, deal price, and structure, is harder to formalize and transmit over distance. Also, as it is common in such transactions that the acquirer and the target are operating within different legal systems, and are subject to differing cultural norms and languages, that whatever information that can be codified empirically may still give rise to information asymmetry between the parties due to differing interpretations. Such barriers make the acquirer's assessment of the potential synergies arising from cross-country M\&As significantly more difficult than in case of within-country M\&As.

Prior literature has found that nearly a quarter of U.S. M\&A deals have shared auditors and that common auditors act as information intermediaries, thus mitigating uncertainty in M\&A transactions resulting in higher quality M\&A deals (eg. Cai et al., 2016 and Dhaliwal et al., 2016). Prior studies analyzing the common auditor effect have however focused on within country deals. In this study we seek to address the Cai et al. (2016) call for further research analyzing the effect of common auditors on M\&A transactions.

Given the higher uncertainty of cross-country M\&A transactions, the need for information intermediaries is greater. However, differences in cultural and legal norms may pose significant barriers to the sharing of information between common auditors. Thus ex-ante it is unclear whether the common audit effect documented in prior literature may be extended to cross-country M\&A transactions.

We find that the use of common auditors give rise to higher quality M\&A transactions, as proxied by higher synergy around the M\&A announcement date, lower premium and a larger 
change in acquirer return on assets post-acquisitions. Moreover, we find that such common auditor effect is even greater for cross-country M\&A deals, which pose additional uncertainty. Such deals include M\&A transactions where the target is small, coming from the high-tech industry, and has growth potential. We also find that the common auditor effect is stronger when the parties operate within jurisdictions with different accounting standards. Our cross-country analyses take two separate cultural measures, the World Value Survey and the Hofstede Indices, and we find that controlling for cultural differences, the use common auditors results in better quality deals. Finally, we compare our results by taking into consideration the potential benefit to only the acquirer and find that the use of common auditors creates value to the acquirer. Taken together these results suggest that the common auditor effect documented in prior literature for within-country M\&A transactions extends to cross-country M\&A transactions.

We note however that in interpreting these results caution should be exercised in that the quantity of information between auditors is unobservable and thus we cannot directly speak to the type, amount and the transfer mechanics of such information. We are also unable to observe when such transfer of information is carried out. Our findings do suggest however that the use of common auditors in M\&As may benefit parties as a result of better access to codified or explicit information such as balance sheets or performance records that are standardized and interpreted correspondingly among parties, thus enabling parties to better mitigate financial risk and determine return optimization. 


\section{References}

Agrawal, A., Cooper, T., Lian, Q. and Wang, Q., 2013. Common advisors in mergers and acquisitions: determinants and consequences. Journal of Law and Economics 56: 691-740.

Ahern, K. R., D. Daminelli, and C. Fracassi. 2015. Lost in translation? The effect of cultural values on mergers around the world. Journal of Financial Economics 117: 165-189.

Arrow, K. J., 1962. Economic welfare and the allocation of resources for invention. In Nelson, R., editor, The Rate and Direction of Inventive Activity, 609-625. Princeton University Press.

Asquith, P., Bruner, R. and Mullins, D., 1983. The gains to bidding firms from merger. Journal of Financial Economics 11: 121-139.

Banker, J., Chang H. and Kao Y-C., 2002. Impact of information technology on public accounting firm productivity. Journal of Information Systems Fall, 209-222.

Blacconiere, W.G., Frederickson J.R., Johnson M.F. and Lewis M.F., 2011. Are voluntary disclosures that disavow the reliability of mandated fair value information informative or opportunistic? Journal of Accounting and Economics 52: 235-251.

Bradley, M., Desai, A. and Kim, E., 1988. Synergistic gains from corporate acquisitions and their division between the stockholders of target and acquiring firms. Journal of Financial Economics 21: 3-40.

Bruner, R. F., 2004. Applied Mergers \& Acquisitions. New Jersey: John Wiley \& Sons.

Cai Y., Yongtae K., Park J.C. and White H.D., 2016. Common auditors in M\&A transactions. Journal of Accounting and Economics. 61: 77-99.

Cai, Y. and Sevilir, M., 2012. Board connections and M\&A transactions. Journal of Financial Economics. 103: 327-349.

Chen, C.W., Collins, D. W., Kravet, T. D. and Mergenthaler, R., 2016. Financial statement comparability and the efficiency of acquisition decisions. Available at SSRN: http://ssrn.com/abstract=2169082.

Datta, D.K. and Puia, G., 1995. Cross-border acquisitions: An examination of the influence of relatedness and cultural fit on shareholder value creation in US acquiring firms. MIR: Management International Review, 337-359. 
Dhaliwal, D.S., Lamoreaux, P.T., Litov, L.P. and Neyland, J.B., 2016. Shared auditors in mergers and acquisitions. Journal of Accounting and Economics 61: 49-76.

Erickson, M., Wang, S. and Zhang, F., 2012. The change in information uncertainty and acquirer wealth losses. Review of Accounting Studies 17: 913-943.

Francis, J.R., Pinnuck, M. and Watanabe, O., 2014. Auditor style and financial statement comparability. Accounting Review 89: 605-633.

Georgieva, D., Jandik, T. and Lee, W.Y., 2012. The impact of laws, regulations, and culture on cross-border joint ventures. Journal of International Financial Markets, Institutions and Money 22: 774-795.

Golubov, A., Petmezas, D., Sougiannis, T. and Travlos, N., 2012. Target firm auditor reputation, information asymmetry, and corporate takeovers. Working Paper. University of Illinois.

Goodman, T., Neamtiu, M., Shroff, N. and White, H., 2014. Management forecast quality and capital investment decisions. Accounting Review 89: 331-365.

Hain, D., Johan, S. and Wang, D., 2015. Determinants of cross-border venture capital investments in emerging and developed economies: The effects of relational and institutional trust. Journal of Business Ethics, 1-22.

Hofstede, G. and Bond, M. H., 1984. Hofstede's culture dimensions. Journal of Cross-Cultural Psychology, 15:417.

Hofstede, G., Hofstede, G. J., and Minkov, M., 2010. Cultures and organizations: Software of the mind. McGraw-Hill London.

Levine, O. 2013. Acquiring Growth. Available at SSRN: http://ssrn.com/abstract=1928255 or http://dx.doi.org/10.2139/ssrn.1928255.

Loughran, T. and Ritter, J., 2004. Why has IPO underpricing changed over time? Financial Management 33: 5-37.

Louis, H., 2005. Acquirers' abnormal returns and the non-Big 4 auditor clientele effect. Journal of Accounting and Economics 40: 75-99. 
Martin, X. and Shalev, R., 2016. Target firm-specific information and expected synergies in acquisitions. Management Science, In press.

McNichols, M. and Stubben, S., 2015. The effect of target-firm accounting quality on valuation in acquisitions. Review of Accounting Studies 20: 110-140.

Moeller, S.B., Schlingemann, F.P. and Stulz, R.M., 2004. Firm size and the gains from acquisitions. Journal of Financial Economics: 73(2), 201-228.

Officer, M.S. 2003. Termination fees in mergers and acquisitions. Journal of Financial Economics 69: 431-467.

Persakis, A. and Iatridis, G.E., 2015. Cost of capital, audit and earnings quality under financial crisis: A global empirical investigation. Journal of International Financial Markets, Institutions and Money 38: 3-24.

Polanyi, M., 1966. Personal knowledge: Towards a post-critical philosophy. Chicago: University of Chicago Press.

Rossi, S., and Volpin, P. F. 2004. Cross-country determinants of mergers and acquisitions. Journal of Financial Economics 74: 277-304.

Sandra C. Vera-Munoz, Joanna L. Ho, and Chee W. Chow. 2006. Enhancing knowledge sharing in public accounting firms. Accounting Horizons 20: 133-155

Servaes, H. and Zenner, M., 1996. The role of investment banks in acquisitions. Review of Financial Studies 9: 787-815

Skaife, H. A. and Wangerin, D.D. 2013. Target financial reporting quality and M\&A deals that go bust. Contemporary Accounting Research 30: 719-749.

Von Hippel, E., 1994. Sticky information and the locus of problem solving: Implications for innovation. Management Science, 40: 429-439.

Wangerin, D. 2016. Do Fools Rush In? The importance of due diligence in M\&A transactions. Available at SSRN: http://ssrn.com/abstract=2118836 or http://dx.doi.org/10.2139/ssrn.2118836.

Winograd, B., Gerson J., and Berlin B. 2000. Audit practices of PricewaterhouseCoopers. Auditing: A Journal of Practice \& Theory Fall, 175-182 
Xie, Y., Yi, H., Zhang, Y., 2013. The value of Big $\mathrm{N}$ target auditors in corporate takeovers. Auditing: A Journal of Practice \& Theory 32: 141-169.

Yan, S., 2015. Managerial attitudes and takeover outcomes: Evidence from corporate filings. Journal of International Financial Markets, Institutions and Money 35: 30-44. 


\section{Appendix 1. Variable Definitions}

\begin{tabular}{|c|c|}
\hline Variable Name & Description [Source] \\
\hline \multicolumn{2}{|l|}{ Dependent Variables } \\
\hline CHG_ROA & $\begin{array}{l}\text { Change in return on assets (ROA). Measured as the difference between 1-year average } \\
\text { ROA of the combined firm after the acquisition and } 1 \text {-year weighted-average ROA of } \\
\text { the acquirer and the target before the acquisition. ROA is measured as operating income } \\
\text { before depreciation at year } t \text { scaled by average of year } t \text { and year } t-1 \text { total assets } \\
\text { [Thomson Reuters] }\end{array}$ \\
\hline SYNERGY & $\begin{array}{l}\text { The sum of the weighted 10-day acquirer and target cumulative abnormal return around } \\
\text { the M\&A announcement date, calculated using the adjusted return [Thomson Reuters, } \\
\text { Thomson One SDC] }\end{array}$ \\
\hline PREMIUM & $\begin{array}{l}\text { The difference between the price offered in the bid and the target's trading price four } \\
\text { weeks' prior [Thomson Reuters, Thomson One SDC] }\end{array}$ \\
\hline \multicolumn{2}{|l|}{$\begin{array}{l}\text { Main Independent } \\
\text { Variables }\end{array}$} \\
\hline SAME_AUDITOR & $\begin{array}{l}\text { An indicator variable equal to one if the acquirer and the target share common auditor, } \\
\text { and zero otherwise. [Thomson Reuters] }\end{array}$ \\
\hline \multicolumn{2}{|c|}{ Acquirer Characteristics } \\
\hline ACQ_ASSETS & $\begin{array}{l}\text { Acquirer's size. Measured as the natural logarithm of acquirer's market value at the end } \\
\text { of the quarter prior to the announcement [Thomson Reuters] }\end{array}$ \\
\hline ACQ_ROA & $\begin{array}{l}\text { Acquirer's return on assets for the year ended before the announcement year, measured } \\
\text { as operating income before depreciation scaled by average total assets [Thomson } \\
\text { Reuters] }\end{array}$ \\
\hline ACQ_LEV & $\begin{array}{l}\text { Acquirer's pre-acquisition leverage. Measured as the sum of long term debt and short } \\
\text { term debt deflated by total assets at the fiscal year end prior to an acquisition } \\
\text { announcement [Thomson Reuters] }\end{array}$ \\
\hline ACQ_MB & $\begin{array}{l}\text { Acquirer's market-to-book. Measured as shares outstanding times stock price divided by } \\
\text { the total equity at the fiscal year end prior to an acquisition announcement [Thomson } \\
\text { Reuters] }\end{array}$ \\
\hline \multicolumn{2}{|l|}{ Target Characteristics } \\
\hline TRG_ASSETS & $\begin{array}{l}\text { Target's size. Measured as the natural logarithm of acquirer's market value at the end of } \\
\text { the quarter prior to the announcement [Thomson Reuters] }\end{array}$ \\
\hline TRG_ROA & $\begin{array}{l}\text { Target's return on assets for the year ended before the announcement year, measured as } \\
\text { operating income before depreciation scaled by average total assets [Thomson Reuters] }\end{array}$ \\
\hline TRG_LEV & $\begin{array}{l}\text { Target's pre-acquisition leverage. Measured as the sum of long term debt and short term } \\
\text { debt deflated by total assets at the fiscal year end prior to an acquisition announcement } \\
\text { [Thomson Reuters] }\end{array}$ \\
\hline TRG_MB & $\begin{array}{l}\text { Target's market-to-book. Measured as shares outstanding times stock price divided by } \\
\text { the total equity at the fiscal year end prior to an acquisition announcement [Thomson } \\
\text { Reuters] }\end{array}$ \\
\hline \multicolumn{2}{|l|}{ Deal Characteristics } \\
\hline SAME_INDUSTRY & $\begin{array}{l}\text { An indicator variable that takes the value } 1 \text { if the acquirer and the target are in the same } \\
\text { industries, and zero otherwise [Thomson One SDC] }\end{array}$ \\
\hline TOEHOLD & $\begin{array}{l}\text { Acquirer's percentage equity ownership in the target firm prior to the deal announcement } \\
\text { [Thomson One SDC] }\end{array}$ \\
\hline TENDER & $\begin{array}{l}\text { An indicator variable that takes the value } 1 \text { if the acquisition is classified as tender offer, } \\
\text { and zero otherwise [Thomson One SDC] }\end{array}$ \\
\hline TARGET_FEE & $\begin{array}{l}\text { An indicator variable that takes the value } 1 \text { if the target has a termination fee, and zero } \\
\text { otherwise [Thomson One SDC] }\end{array}$ \\
\hline CASH & $\begin{array}{l}\text { An indicator variable that takes the value } 1 \text { if the acquisition was financed at least } 90 \\
\text { percent by cash, and zero otherwise [Thomson One SDC] }\end{array}$ \\
\hline STOCK & An indicator variable that takes the value 1 if the acquisition was financed at least 90 \\
\hline
\end{tabular}


TRG_HIGHTECH

RELATIVE

DIFF_ACC_STD

Country Characteristics

LEGOR_UK_ACQ

LEGOR_UK_TRG

CREDITOR_ACQ

CREDITOR_TRG

GDPPC_ACQ

Cultural Differences

TRUST

INDIVIDUALISM

PDI

IDV

MAS

UAI

LTOWVS

IVR
GDPPC_TRG

percent by acquirer's stocks, and zero otherwise [Thomson One SDC]

An indicator variable equals one if the acquirer and the target are both from the hightech industries as defined in Loughran and Ritter (2004) and zero otherwise. [Thomson One SDC]

Relative deal size. Measured as the ratio of the transaction value to the market value of the bidder [Thomson One SDC, CRSP]

An indicator variable that takes the value 1 if acquirer and the target have different accounting standards, and zero otherwise [www.ifrs.org]

An indicator variable equal to one if the acquirer firm is from a Common Law region, and zero otherwise [LLSV, 2001]

An indicator variable equal to one if the target firm is from a Common Law region, and zero otherwise [LLSV, 2001]

An index aggregating different creditor rights of the acquirer firm's country from La Porta et al. (1998). The index is formed by adding 1 when (1) the country imposes restrictions, such as creditors' consent or minimum dividends to file for reorganization; (2) secured creditors are able to gain possession of their security once the reorganization petition has been approved (no automatic stay); (3) secured creditors are ranked first in the distribution of the proceeds that result from the disposition of the assets of a bankrupt firm; and (4) the debtor does not retain the administration of its property pending the resolution of the reorganization

An index aggregating different creditor rights of the target firm's country from La Porta et al. (1998)

GDP per capital in the acquirer firm's country [World Bank]

GDP per capital in the target firm's country [World Bank]

Average answer to the following question: "Generally speaking, would you say that (1) Most people can be trusted (2) Need to be very careful" (Question V25) [Source: World Values Survey]

Average answer to the following question: "Incomes should be more equal or We need larger income differences as incentives for individual effort" (Question V141) [Source: World Values Survey]

Power Distance Index of the respective target and acquirer countries (see http://geerthofstede.com/national-culture.html)

Individualism versus Collectivism of the respective target and acquirer countries (see http://geerthofstede.com/national-culture.html)

Masculinity versus Femininity of the respective target and acquirer countries (see http://geerthofstede.com/national-culture.html)

Uncertainty Avoidance Index of the respective country target and acquirer countries (see http://geerthofstede.com/national-culture.html)

Long -Term Orientation versus Short-Term Normative Orientation of the respective target and acquirer countries (see http://geert-hofstede.com/nationalculture.html) Indulgence versus Restraint of the respective target and acquirer countries (see http://geert-hofstede.com/nationalculture.html)

Note: All accounting variables are as of the latest fiscal year ending before the acquisition announcement date. 
Table 1. Sample distribution

This table shows the distribution of M\&A transactions across the sample period. The sample includes all cross-country acquisitions announced between 2000 and 2014 in which the acquirer owned less than $50 \%$ of the target prior to the purchase and acquired $100 \%$ of the target.

\begin{tabular}{|c|c|c|c|c|c|c|}
\hline \multirow[b]{2}{*}{ Year } & \multicolumn{2}{|c|}{ Full sample } & \multicolumn{2}{|c|}{$\begin{array}{c}\text { Common auditor } \\
\text { deals }\end{array}$} & \multicolumn{2}{|c|}{$\begin{array}{c}\text { Non-common auditor } \\
\text { deals }\end{array}$} \\
\hline & Number & Percentage & Number & Percentage & Number & Percentage \\
\hline 2000 & 4 & 1.14 & 2 & 3.23 & 2 & 0.69 \\
\hline 2001 & 19 & 5.41 & 4 & 6.45 & 15 & 5.19 \\
\hline 2002 & 2 & 0.57 & 1 & 1.61 & 1 & 0.35 \\
\hline 2003 & 7 & 1.99 & 3 & 4.84 & 4 & 1.38 \\
\hline 2004 & 18 & 5.13 & 5 & 8.06 & 13 & 4.50 \\
\hline 2005 & 22 & 6.27 & 6 & 9.68 & 16 & 5.54 \\
\hline 2006 & 29 & 8.26 & 6 & 9.68 & 23 & 7.96 \\
\hline 2007 & 33 & 9.40 & 14 & 22.58 & 19 & 6.57 \\
\hline 2008 & 20 & 5.70 & 1 & 1.61 & 19 & 6.57 \\
\hline 2009 & 22 & 6.27 & 1 & 1.61 & 21 & 7.27 \\
\hline 2010 & 43 & 12.25 & 4 & 6.45 & 39 & 13.49 \\
\hline 2011 & 30 & 8.55 & 4 & 6.45 & 26 & 9.00 \\
\hline 2012 & 47 & 13.39 & 7 & 11.29 & 40 & 13.84 \\
\hline 2013 & 23 & 6.55 & 2 & 3.23 & 21 & 7.27 \\
\hline 2014 & 32 & 9.12 & 2 & 3.23 & 30 & 10.38 \\
\hline Total & 351 & 100 & 62 & 100 & 289 & 100 \\
\hline
\end{tabular}




\section{Table 2. Descriptive statistics}

This table shows summary statistics for the variables used in our base model. The sample includes all cross-country mergers and acquisitions announced between 2000 and 2014 in which the acquirer owned less than $50 \%$ of the target prior to the purchase and acquired $100 \%$ of the target. The sample size consists of 351 deals.

\begin{tabular}{|c|c|c|c|c|c|c|c|c|}
\hline & \multicolumn{2}{|c|}{ Full sample } & \multicolumn{2}{|c|}{$\begin{array}{c}\text { Common } \\
\text { auditor deals }\end{array}$} & \multicolumn{2}{|c|}{$\begin{array}{c}\text { Non-common } \\
\text { auditor deals }\end{array}$} & \multirow{2}{*}{$\begin{array}{c}\text { Difference } \\
\text { in Mean }\end{array}$} & \multirow[b]{2}{*}{ t-stat } \\
\hline & Mean & SD & Mean & SD & Mean & $\mathrm{SD}$ & & \\
\hline \multicolumn{9}{|c|}{ Announcement returns } \\
\hline SYNERGY[-5;5] & 0.03 & 0.12 & 0.05 & 0.18 & 0.03 & 0.09 & 0.02 & -1.48 \\
\hline SYNERGY[-10;10] & 0.04 & 0.14 & 0.06 & 0.22 & 0.04 & 0.12 & 0.02 & -1.02 \\
\hline SYNERGY[-20;20] & 0.05 & 0.18 & 0.09 & 0.26 & 0.04 & 0.15 & $0.05 *$ & -2.00 \\
\hline \multicolumn{9}{|l|}{ Controls } \\
\hline SAME_INDUSTRY & 0.62 & 0.49 & 0.61 & 0.49 & 0.62 & 0.49 & -0.01 & 0.15 \\
\hline TOEHOLD & 0.10 & 0.30 & 0.13 & 0.34 & 0.10 & 0.30 & 0.03 & -0.76 \\
\hline TENDER & 0.38 & 0.49 & 0.39 & 0.49 & 0.37 & 0.48 & 0.01 & -0.20 \\
\hline TARGET_FEE & 0.53 & 0.50 & 0.52 & 0.50 & 0.53 & 0.50 & -0.01 & 0.19 \\
\hline $\mathrm{CASH}$ & 0.55 & 0.50 & 0.47 & 0.50 & 0.57 & 0.50 & -0.10 & 1.48 \\
\hline STOCK & 0.19 & 0.40 & 0.26 & 0.44 & 0.18 & 0.38 & 0.08 & -1.41 \\
\hline TRG_HIGHTECH & 0.37 & 0.48 & 0.29 & 0.46 & 0.39 & 0.49 & -0.10 & 1.44 \\
\hline TRG_ASSETS & 5.64 & 2.07 & 6.18 & 2.15 & 5.53 & 2.04 & $0.65^{* *}$ & -2.24 \\
\hline ACQ_ASSETS & 8.06 & 2.36 & 8.31 & 2.08 & 8.00 & 2.42 & 0.31 & -0.93 \\
\hline TRG_ROA & -0.04 & 0.22 & -0.03 & 0.26 & -0.04 & 0.21 & 0.01 & -0.29 \\
\hline ACQ_ROA & 0.02 & 0.15 & 0.02 & 0.16 & 0.02 & 0.15 & -0.00 & -0.06 \\
\hline TRG_LEVERAGE & 0.15 & 0.18 & 0.16 & 0.19 & 0.14 & 0.17 & 0.02 & -0.84 \\
\hline ACQ_LEVERAGE & 0.19 & 0.15 & 0.22 & 0.15 & 0.18 & 0.15 & 0.03 & -1.58 \\
\hline TRG_MB & 2.43 & 2.88 & 3.06 & 4.09 & 2.29 & 2.54 & $0.77 *$ & -1.91 \\
\hline ACQ_MB & 2.57 & 2.80 & 2.73 & 3.37 & 2.53 & 2.66 & 0.20 & -0.51 \\
\hline
\end{tabular}


Table 3. Correlation matrix

This table shows Pearson correlation for the variables used in our base model. N=351.

\begin{tabular}{|c|c|c|c|c|c|c|c|c|c|c|c|c|c|c|c|c|c|c|}
\hline & & (1) & (2) & (3) & (4) & (5) & $(6)$ & (7) & $(8)$ & (9) & $(10)$ & (11) & (12) & (13) & (14) & (15) & (16) & (17) \\
\hline (1) & SYNERGY & 1.00 & & & & & & & & & & & & & & & & \\
\hline (2) & SAME_AUDITOR & 0.08 & 1.00 & & & & & & & & & & & & & & & \\
\hline (3) & SAME_INDUSTRY & -0.05 & -0.01 & 1.00 & & & & & & & & & & & & & & \\
\hline (4) & TOEHOLD & -0.03 & 0.04 & 0.09 & 1.00 & & & & & & & & & & & & & \\
\hline (5) & TENDER & -0.03 & 0.01 & -0.08 & $0.13^{*}$ & 1.00 & & & & & & & & & & & & \\
\hline (6) & TARGET_FEE & -0.06 & -0.01 & 0.02 & $-0.17 *$ & $-0.16^{*}$ & 1.00 & & & & & & & & & & & \\
\hline (7) & CASH & 0.03 & -0.08 & $-0.16^{*}$ & 0.02 & $0.21 *$ & 0.07 & 1.00 & & & & & & & & & & \\
\hline (8) & STOCK & -0.08 & 0.08 & $0.23 *$ & 0.10 & $-0.20 *$ & -0.06 & $-0.54^{*}$ & 1.00 & & & & & & & & & \\
\hline (9) & TRG_HIGHTECH & 0.06 & -0.08 & -0.03 & -0.10 & 0.01 & 0.04 & $0.13 *$ & -0.09 & 1.00 & & & & & & & & \\
\hline (10) & TRG_ASSETS & -0.05 & $0.12 *$ & -0.05 & 0.07 & 0.05 & 0.08 & -0.04 & -0.10 & $-0.17 *$ & 1.00 & & & & & & & \\
\hline (11) & ACQ_ASSETS & $-0.21^{*}$ & 0.05 & -0.10 & 0.03 & $0.16^{*}$ & $0.15^{*}$ & $0.23 *$ & $-0.31^{*}$ & -0.07 & $0.67 *$ & 1.00 & & & & & & \\
\hline (12) & TRG_ROA & -0.09 & 0.02 & $-0.12 *$ & -0.03 & $0.19 *$ & -0.01 & $0.21 *$ & $-0.29 *$ & $-0.15^{*}$ & $0.36^{*}$ & $0.32 *$ & 1.00 & & & & & \\
\hline (13) & ACQ_ROA & -0.04 & 0.00 & $-0.11^{*}$ & 0.04 & $0.12 *$ & -0.00 & $0.23 *$ & $-0.27 *$ & -0.07 & $0.25 *$ & $0.44 *$ & $0.25^{*}$ & 1.00 & & & & \\
\hline (14) & TRG_LEVERAGE & $0.14^{*}$ & 0.05 & $-0.15^{*}$ & 0.03 & -0.01 & 0.01 & -0.04 & $-0.11 *$ & $-0.14^{*}$ & $0.32 *$ & $0.14^{*}$ & 0.05 & 0.09 & 1.00 & & & \\
\hline (15) & ACQ_LEVERAGE & 0.08 & 0.08 & -0.10 & 0.02 & 0.08 & 0.05 & 0.01 & -0.08 & $-0.13^{*}$ & $0.13 *$ & $0.14 *$ & 0.06 & -0.03 & $0.27 *$ & 1.00 & & \\
\hline (16) & TRG_MB & $0.24 *$ & 0.10 & -0.01 & 0.02 & -0.07 & 0.03 & $-0.11^{*}$ & $0.11 *$ & 0.06 & -0.09 & -0.08 & $-0.15^{*}$ & -0.01 & 0.06 & -0.03 & 1.00 & \\
\hline$(17)$ & ACQ_MB & $0.18^{*}$ & 0.03 & 0.05 & -0.01 & -0.03 & 0.02 & -0.03 & 0.10 & $0.11^{*}$ & $-0.16^{*}$ & $-0.31 *$ & -0.10 & $-0.18^{*}$ & -0.01 & $0.12 *$ & $0.17 *$ & 1.00 \\
\hline
\end{tabular}

Note: $* \mathrm{p}<0.05$. The correlations with country characteristics are omitted. They are available from the authors upon request. 


\section{Table 4. The effect of same auditor on M\&A synergies}

This table shows the main results of the regression analysis where the main dependent variable is SYNERGY[-5;5]. In Model 1 we present the results where we calculate the synergies based on adjusted return and in Model 2 we present the results where we calculate the synergies the Market Model. The sample consists of all completed mergers and acquisitions announced between 2000 and 2014 in which the acquirer owned less than 50\% of the target prior to the purchase and acquired 100\% of the target. All regressions include constant, year and industry dummies. All variables are defined in Appendix 1. ***,**, and * represent 1\%, 5\%, and 10\% significance levels respectively. Standard errors are clustered by year and industry.

\begin{tabular}{|c|c|c|c|c|}
\hline \multirow{2}{*}{$\begin{array}{l}\text { Variable } \\
\text { SAME_AUDITOR }\end{array}$} & \multicolumn{2}{|c|}{$(1)$} & \multicolumn{2}{|c|}{$(2)$} \\
\hline & $0.018 * * *$ & (3.31) & $0.049 * * *$ & $(2.79)$ \\
\hline SAME_INDUSTRY & -0.001 & $(-0.10)$ & $0.025 * * *$ & $(3.11)$ \\
\hline TOEHŌ'D & $-0.026 * * *$ & $(-18.08)$ & $-0.033 * * *$ & $(-5.90)$ \\
\hline TENDER & $0.010 * * *$ & $(3.97)$ & $0.018 *$ & $(1.74)$ \\
\hline TARGET_FEE & -0.005 & $(-0.24)$ & 0.009 & $(0.48)$ \\
\hline $\mathrm{CASH}$ & 0.018 & $(0.81)$ & 0.034 & $(1.53)$ \\
\hline STOCK & $-0.052 * *$ & $(-2.26)$ & $-0.070 * *$ & $(-2.23)$ \\
\hline TRG_HIGHTECH & -0.005 & $(-0.37)$ & -0.005 & $(-0.28)$ \\
\hline TRG_ASSETS & $0.013 * *$ & $(2.58)$ & $0.020 * * *$ & $(4.31)$ \\
\hline ACQ_ASSETS & $-0.027 * * *$ & $(-4.49)$ & $-0.033 * * *$ & $(-12.73)$ \\
\hline TRG_ROA & -0.025 & $(-0.41)$ & -0.030 & $(-0.32)$ \\
\hline ACQ_ROA & 0.063 & $(1.65)$ & $0.106 * * *$ & $(3.91)$ \\
\hline TRG_LEVERAGE & 0.026 & $(0.69)$ & 0.041 & $(0.84)$ \\
\hline ACQ_LEVERAGE & 0.054 & $(1.28)$ & 0.028 & $(0.37)$ \\
\hline TRG_MB & 0.010 & $(1.51)$ & $0.012 * *$ & $(2.11)$ \\
\hline ACQ_MB & 0.000 & $(0.08)$ & -0.000 & $(-0.07)$ \\
\hline LEGOR_UK_ACQ & $-0.013 * *$ & $(-2.02)$ & -0.026 & $(-1.65)$ \\
\hline LEGOR_UK_TRG & 0.018 & $(0.68)$ & 0.002 & $(0.06)$ \\
\hline CREDITOR_ACQ & -0.002 & $(-0.37)$ & 0.003 & $(0.31)$ \\
\hline CREDITOR_TRG & -0.012 & $(-1.32)$ & -0.009 & $(-1.29)$ \\
\hline GDPPC_ACQ & $0.010 * * *$ & (11.72) & 0.015 & $(1.50)$ \\
\hline GDPPC_TRG & $-0.023 * * *$ & $(-3.03)$ & $-0.023 * * *$ & $(-3.02)$ \\
\hline OBSERVATIONS & \multirow{2}{*}{\multicolumn{2}{|c|}{$\begin{array}{r}351 \\
0.328\end{array}$}} & \multicolumn{2}{|c|}{242} \\
\hline R-SQ & & & 0.4 & \\
\hline
\end{tabular}




\section{Table 5. Common auditor and target size}

This table shows the results of the regression analysis where the main dependent variable is SYNERGY [-5;5]. The sample consists of all completed mergers and acquisitions announced between 2000 and 2014 in which the acquirer owned less than 50\% of the target prior to the purchase and acquired $100 \%$ of the target. INV_TRG_ASSETS is the inverse of TRG_ASSETS. All regressions include constant, year and industry dummies. All variables are defined in Appendix 1.***,**, and * represent 1\%, 5\%, and 10\% significance levels respectively. Standard errors are clustered by year and industry.

\begin{tabular}{|c|c|c|c|c|}
\hline \multirow{2}{*}{$\begin{array}{l}\text { Variable } \\
\text { INV_TRG_ASSETS*SAME_AUDITOR }\end{array}$} & \multicolumn{2}{|c|}{$(1)$} & \multicolumn{2}{|c|}{$(2)$} \\
\hline & 0.599 & (1.31) & $0.616 *$ & (1.69) \\
\hline SAME_AUDITOR & -0.092 & $(-1.38)$ & -0.097 & $(-1.50)$ \\
\hline INV_TRG_ASSETS & 0.046 & $(1.27)$ & -0.066 & $(-0.92)$ \\
\hline SAME_INDUSTRY & & & 0.005 & $(0.52)$ \\
\hline TOEHOLD & & & $-0.022 * *$ & $(-2.54)$ \\
\hline TENDER & & & 0.003 & $(0.71)$ \\
\hline TARGET_FEE & & & -0.003 & $(-0.16)$ \\
\hline CASH & & & 0.004 & $(0.22)$ \\
\hline STOCK & & & $-0.053 * *$ & $(-2.63)$ \\
\hline TRG_HIGHTECH & & & -0.012 & $(-1.00)$ \\
\hline ACQ_ASSETS & & & $-0.020 * * *$ & $(-4.99)$ \\
\hline TRG_ROA & & & 0.023 & $(0.56)$ \\
\hline ACQ_ROA & & & $0.081 * *$ & $(2.20)$ \\
\hline TRG_LEVERAGE & & & 0.061 & $(1.29)$ \\
\hline ACQ_LEVERAGE & & & 0.028 & $(0.50)$ \\
\hline TRG_MB & & & 0.008 & $(1.45)$ \\
\hline ACQ_MB & & & 0.002 & $(0.37)$ \\
\hline LEGOR_UK_ACQ & & & $-0.018 * * *$ & $(-5.99)$ \\
\hline LEGOR_UK_TRG & & & 0.012 & $(0.52)$ \\
\hline CREDITOR_ACQ & & & -0.003 & $(-0.57)$ \\
\hline CREDITOR_TRG & & & -0.010 & $(-1.47)$ \\
\hline GDPPC_ACQ & & & $0.009 * * *$ & $(3.28)$ \\
\hline GDPPC_TRG & & & $-0.018 * * *$ & $(-3.15)$ \\
\hline OBSERVATIONS & & & 35 & \\
\hline R-SQ & & & 0.34 & \\
\hline
\end{tabular}




\section{Table 6. Common auditor and target industry}

This table shows the main results of the regression analysis where the main dependent variable is SYNERGY [-5;5]. The sample consists of all completed mergers and acquisitions announced between 2000 and 2014 in which the acquirer owned less than $50 \%$ of the target prior to the purchase and acquired $100 \%$ of the target. All regressions include constant, year and industry dummies. All variables are defined in Appendix 1. ***,**, and * represent 1\%, $5 \%$, and $10 \%$ significance levels respectively. Standard errors are clustered by year and industry.

\begin{tabular}{|c|c|c|c|c|}
\hline Variable & $(1)$ & & ( & \\
\hline TRG_HIGHTECH*SAME_AUDITOR & $0.150 *$ & (1.89) & $0.097 *$ & (1.90) \\
\hline SAME_AUDITOR & $-0.022 * * *$ & $(-2.90)$ & -0.012 & $(-1.07)$ \\
\hline TRG_HIGHTECH & $-0.026 * * *$ & $(-2.70)$ & -0.021 & $(-1.18)$ \\
\hline SAME_INDUSTRY & & & 0.002 & $(0.20)$ \\
\hline TOEHOLD & & & $-0.024 * * *$ & $(-3.81)$ \\
\hline TENDER & & & $0.014 * * *$ & $(7.13)$ \\
\hline TARGET_FEE & & & -0.003 & $(-0.15)$ \\
\hline CASH & & & 0.013 & $(0.62)$ \\
\hline STOCK & & & $-0.051 * *$ & $(-2.25)$ \\
\hline TRG_ASSETS & & & $0.013 * * *$ & $(2.67)$ \\
\hline ACQ_ASSETS & & & $-0.025 * * *$ & $(-4.51)$ \\
\hline TRG_ROA & & & -0.025 & $(-0.46)$ \\
\hline ACQ_ROA & & & $0.070 * *$ & $(2.11)$ \\
\hline TRG_LEVERAGE & & & 0.027 & $(0.77)$ \\
\hline ACQ_LEVERAGE & & & 0.049 & $(1.05)$ \\
\hline TRG_MB & & & 0.009 & $(1.48)$ \\
\hline ACQ_MB & & & 0.001 & $(0.10)$ \\
\hline LEGOR_UK_ACQ & & & $-0.011 *$ & $(-1.73)$ \\
\hline LEGOR_UK_TRG & & & 0.019 & $(0.64)$ \\
\hline CREDITOR_ACQ & & & -0.002 & $(-0.37)$ \\
\hline CREDITOR_TRG & & & -0.012 & $(-1.32)$ \\
\hline GDPPC_ACQ & & & 0.008 & $(1.07)$ \\
\hline GDPPC_TRG & & & $-0.019 * * *$ & $(-2.66)$ \\
\hline OBSERVATIONS & 351 & & 35 & \\
\hline R-SQ & 0.190 & & 0.346 & \\
\hline
\end{tabular}




\section{Table 7. Common auditor and target growth}

This table shows the main results of the regression analysis where the main dependent variable is SYNERGY [-5;5]. The sample consists of all completed mergers and acquisitions announced between 2000 and 2014 in which the acquirer owned less than 50\% of the target prior to the purchase and acquired $100 \%$ of the target. All regressions include constant, year and industry dummies. All variables are defined in Appendix 1. ***, **, and * represent 1\%, $5 \%$, and $10 \%$ significance levels respectively. Standard errors are clustered by year and industry.

\begin{tabular}{|c|c|c|c|c|}
\hline \multirow{2}{*}{$\begin{array}{l}\text { Variable } \\
\text { TRG_MB*SAME_AUDITO } \\
\text { R }\end{array}$} & \multicolumn{2}{|c|}{ (1) } & \multicolumn{2}{|c|}{$(2)$} \\
\hline & $0.026 * * *$ & (3.12) & $0.025 * * *$ & (4.41) \\
\hline SAME_AUDITOR & $-0.056^{*}$ & $(-1.93)$ & $-0.052 * *$ & $(-2.60)$ \\
\hline TRG_MB & -0.0003 & $(-0.16)$ & 0.001 & $(0.58)$ \\
\hline SAME_INDUSTRY & & & 0.009 & $(1.04)$ \\
\hline TOEHOLD & & & $-0.034 *$ & $(-1.84)$ \\
\hline TENDER & & & 0.006 & $(0.70)$ \\
\hline TARGET_FEE & & & -0.006 & $(-0.29)$ \\
\hline CASH & & & 0.024 & $(1.29)$ \\
\hline STOCK & & & $-0.054 * *$ & $(-2.57)$ \\
\hline TRG_HIGHTECH & & & -0.009 & $(-0.78)$ \\
\hline TRG_ASSETS & & & $0.013 * *$ & $(2.55)$ \\
\hline ACQ_ASSETS & & & $-0.025 * * *$ & $(-4.74)$ \\
\hline TRG_ROA & & & -0.040 & $(-0.85)$ \\
\hline ACQ_ROA & & & $0.073 * *$ & $(2.03)$ \\
\hline TRG_LEVERAGE & & & 0.014 & $(0.31)$ \\
\hline ACQ_LEVERAGE & & & $0.063 *$ & $(1.81)$ \\
\hline ACQ_MB & & & -0.001 & $(-0.40)$ \\
\hline LEGOR_UK_ACQ & & & $-0.017 * * *$ & $(-2.71)$ \\
\hline LEGOR_UK_TRG & & & 0.015 & $(0.72)$ \\
\hline CREDITOR_ACQ & & & -0.001 & $(-0.13)$ \\
\hline CREDITOR_TRG & & & -0.011 & $(-1.51)$ \\
\hline GDPPC_ACQ & & & $0.011 * * *$ & $(2.67)$ \\
\hline GDPPC_TRG & & & $-0.021 * * *$ & $(-2.92)$ \\
\hline OBSERVATIONS & 351 & & 35 & \\
\hline R-SQ & 0.271 & & 0.39 & \\
\hline
\end{tabular}




\section{Table 8. Different accounting standards}

This table shows the main results of the regression analysis where the main dependent variable is SYNERGY [-5;5]. The sample consists of all completed mergers and acquisitions announced between 2000 and 2014 in which the acquirer owned less than 50\% of the target prior to the purchase and acquired $100 \%$ of the target. All regressions include constant, year and industry dummies. All variables are defined in Appendix 1. ***, **, and * represent 1\%, $5 \%$, and $10 \%$ significance levels respectively. Standard errors are clustered by year and industry.

\begin{tabular}{|c|c|c|c|c|}
\hline \multirow{2}{*}{$\begin{array}{l}\text { Variable } \\
\text { DIFF_ACC_STD* } \\
\text { SAME_AUDITOR }\end{array}$} & \multicolumn{2}{|c|}{$(1)$} & \multicolumn{2}{|c|}{ (2) } \\
\hline & 0.104* & (1.67) & $0.085 * *$ & (2.29) \\
\hline SAME_AUDITOR & -0.026 & $(-1.13)$ & -0.021 & $(-0.92)$ \\
\hline DIFF_ACC_STD & 0.013 & $(0.74)$ & 0.002 & $(0.10)$ \\
\hline SAME_INDUSTRY & & & -0.005 & $(-0.32)$ \\
\hline TOEHOLD & & & $-0.029 * * *$ & $(-13.37)$ \\
\hline TENDER & & & 0.007 & $(1.20)$ \\
\hline TARGET_FEE & & & -0.003 & $(-0.18)$ \\
\hline CASH & & & 0.018 & $(0.86)$ \\
\hline STOCK & & & $-0.050 * *$ & $(-2.11)$ \\
\hline TRG_HIGHTECH & & & -0.006 & $(-0.35)$ \\
\hline TRG_ASSETS & & & $0.013 * *$ & $(2.46)$ \\
\hline ACQ_ASSETS & & & $-0.026 * * *$ & $(-4.82)$ \\
\hline TRG_ROA & & & -0.022 & $(-0.37)$ \\
\hline ACQ_ROA & & & $0.065^{*}$ & $(1.74)$ \\
\hline TRG_LEVERAGE & & & 0.019 & $(0.50)$ \\
\hline ACQ_LEVERAGE & & & 0.062 & (1.37) \\
\hline TRG_MB & & & 0.009 & $(1.56)$ \\
\hline ACQ_MB & & & 0.000 & $(0.09)$ \\
\hline LEGOR_UK_ACQ & & & $-0.016^{* *}$ & $(-2.37)$ \\
\hline LEGOR_UK_TRG & & & 0.008 & $(0.37)$ \\
\hline CREDITOR_ACQ & & & 0.000 & $(0.05)$ \\
\hline CREDITOR_TRG & & & -0.009 & $(-1.16)$ \\
\hline GDPPC_ACQ & & & 0.009 & $(0.06)$ \\
\hline GDPPC_TRG & & & $-0.020 * *$ & $(-2.35)$ \\
\hline OBSERVATIONS & \multicolumn{2}{|c|}{351} & \multicolumn{2}{|c|}{351} \\
\hline R-SQ & \multicolumn{2}{|c|}{0.181} & \multicolumn{2}{|c|}{0.347} \\
\hline
\end{tabular}


Table 9. The effect of same auditor on M\&A premium

This table shows the main results of the regression analysis where the main dependent variable is PREMIUM. The sample consists of all completed mergers and acquisitions announced between 2000 and 2014 in which the acquirer owned less than 50\% of the target prior to the purchase and acquired $100 \%$ of the target. All regressions include constant, year and industry dummies. All variables are defined in Appendix 1. ***, **, and * represent 1\%, $5 \%$, and $10 \%$ significance levels respectively. Standard errors are clustered by year and industry.

\begin{tabular}{|c|c|c|c|c|}
\hline \multirow{2}{*}{$\begin{array}{l}\text { Variable } \\
\text { SAME_AUDITOR }\end{array}$} & \multicolumn{2}{|c|}{$(1)$} & \multicolumn{2}{|c|}{ (2) } \\
\hline & $-11.294 * *$ & $(-2.50)$ & $-9.024 *$ & $(-1.71)$ \\
\hline SAME_INDUSTRY & & & $3.410 *$ & $(1.90)$ \\
\hline TOEHOLD & & & -4.566 & $(-0.73)$ \\
\hline TENDER & & & $9.904 * * *$ & $(7.18)$ \\
\hline TARGET_FEE & & & $-4.537 *$ & $(-1.70)$ \\
\hline $\mathrm{CASH}$ & & & -9.495 & $(-1.39)$ \\
\hline STOCK & & & $-12.314 * * *$ & $(-5.80)$ \\
\hline TRG_HIGHTECH & & & 4.320 & $(0.64)$ \\
\hline TRG_ASSETS & & & $-2.837 * *$ & $(-2.39)$ \\
\hline ACQ_ASSETS & & & -2.079 & $(-1.31)$ \\
\hline TRG_ROA & & & -2.640 & $(-0.42)$ \\
\hline ACQ_ROA & & & 17.525 & $(1.60)$ \\
\hline TRG_LEVERAGE & & & -3.561 & $(-0.26)$ \\
\hline ACQ_LEVERAGE & & & -3.374 & $(-0.25)$ \\
\hline TRG_MB & & & -0.347 & $(-0.39)$ \\
\hline ACQ_MB & & & 0.444 & $(0.46)$ \\
\hline LEGOR_UK_ACQ & & & -1.275 & $(-0.41)$ \\
\hline LEGOR_UK_TRG & & & $15.551 * * *$ & $(2.95)$ \\
\hline CREDITOR_ACQ & & & 1.482 & $(0.88)$ \\
\hline CREDITOR_TRG & & & -1.392 & $(-1.00)$ \\
\hline GDPPC_ACQ & & & 2.678 & $(0.82)$ \\
\hline GDPPC_TRG & & & -0.252 & $(-0.05)$ \\
\hline OBSERVATIONS & \multicolumn{2}{|c|}{287} & \multicolumn{2}{|c|}{287} \\
\hline R-SQ & \multicolumn{2}{|c|}{0.064} & \multicolumn{2}{|c|}{0.138} \\
\hline
\end{tabular}


Table 10. The effect of common auditor on M\&A performance

This table shows the main results of the regression analysis where the main dependent variable is CHG_ROA. The sample consists of all completed mergers and acquisitions announced between 2000 and 2014 in which the acquirer owned less than 50\% of the target prior to the purchase and acquired $100 \%$ of the target. All regressions include constant, year and industry dummies. All variables are defined in Appendix 1. ***, **, and * represent 1\%, $5 \%$, and $10 \%$ significance levels respectively. Standard errors are clustered by year and industry.

\begin{tabular}{|c|c|c|c|c|}
\hline \multirow{2}{*}{$\begin{array}{l}\text { Variable } \\
\text { SAME_AUDITOR }\end{array}$} & \multicolumn{2}{|c|}{$(1)$} & \multicolumn{2}{|c|}{$(2)$} \\
\hline & $0.120 * * *$ & (3.18) & $0.130 * * *$ & (3.73) \\
\hline SAME_INDUSTRY & & & 0.043 & $(1.12)$ \\
\hline TOEHOLD & & & -0.074 & $(-0.96)$ \\
\hline TENDER & & & 0.066 & $(1.30)$ \\
\hline TARGET_FEE & & & 0.008 & $(0.14)$ \\
\hline $\mathrm{CASH}$ & & & 0.031 & $(0.35)$ \\
\hline STOCK & & & 0.201 & $(0.67)$ \\
\hline TRG_HIGHTECH & & & -0.078 & $(-0.91)$ \\
\hline TRG_ASSETS & & & $-0.043 * * *$ & $(-2.85)$ \\
\hline ACQ_ASSETS & & & $0.069 * * *$ & $(2.87)$ \\
\hline TRG_ROA & & & -0.299 & $(-1.23)$ \\
\hline ACQ_ROA & & & $2.511 * * *$ & $(4.03)$ \\
\hline TRG_LEVERAGE & & & 0.015 & $(0.13)$ \\
\hline ACQ_LEVERAGE & & & 0.066 & $(0.17)$ \\
\hline TRG_MB & & & 0.004 & $(0.34)$ \\
\hline ACQ_MB & & & 0.023 & $(1.45)$ \\
\hline LEGOR_UK_ACQ & & & -0.004 & $(-0.13)$ \\
\hline LEGOR_UK_TRG & & & $-0.105^{* *}$ & $(-2.12)$ \\
\hline CREDITOR_ACQ & & & 0.001 & $(0.03)$ \\
\hline CREDITOR_TRG & & & $-0.073 * * *$ & $(-3.99)$ \\
\hline GDPPC_ACQ & & & $0.027 * * *$ & $(3.02)$ \\
\hline GDPPC_TRG & & & $-0.073^{*}$ & $(-1.71)$ \\
\hline OBSERVATIONS & 349 & & & \\
\hline R-SQ & 0.048 & & 0.3 & \\
\hline
\end{tabular}


Table 11. Same auditor, synergies and cultural differences

This table shows the results of the regression analysis where the main dependent variable is SYNERGY [-5;5]. The sample consists of all completed mergers and acquisitions announced between 2000 and 2014 in which the acquirer owned less than $50 \%$ of the target prior to the purchase and acquired $100 \%$ of the target. $|\Delta|$ indicates the absolute difference between the acquirer and target nation variables. All regressions include constant, year and industry dummies. All variables are defined in Appendix 1. ***,**, and * represent 1\%, 5\%, and 10\% significance levels respectively. Standard errors are clustered by year and industry.

\begin{tabular}{|c|c|c|c|c|}
\hline \multirow{2}{*}{$\begin{array}{l}\text { Variable } \\
\text { SAME_AUDITOR }\end{array}$} & \multicolumn{2}{|c|}{$(1)$} & \multicolumn{2}{|c|}{ (2) } \\
\hline & $0.036 * * *$ & $(2.83)$ & $\mathbf{0 . 0 3 8} * * *$ & (3.00) \\
\hline $\mathrm{LN}(1+|\overline{\mathrm{TR} U S T}|)$ & 0.166 & $(1.60)$ & & \\
\hline LN $(1+\mid \Delta$ INDIVIDUALISM $\mid)$ & 0.010 & $(0.85)$ & & \\
\hline $\mathrm{LN}(1+|\Delta \mathrm{PDI}|)$ & & & $0.029 * *$ & $(2.50)$ \\
\hline $\mathrm{LN}(1+|\Delta \mathrm{IDV}|)$ & & & 0.001 & $(0.19)$ \\
\hline $\mathrm{LN}(1+|\Delta \mathrm{MAS}|)$ & & & 0.014 & $(1.20)$ \\
\hline $\mathrm{LN}(1+|\Delta \mathrm{UAI}|)$ & & & $-0.019 * * *$ & $(-3.29)$ \\
\hline $\mathrm{LN}(1+|\Delta \mathrm{LTOWVS}|)$ & & & 0.019 & $(1.43)$ \\
\hline $\mathrm{LN}(1+|\Delta \mathrm{IVR}|)$ & & & -0.010 & $(-1.07)$ \\
\hline SAME_INDUSTRY & -0.001 & $(-0.15)$ & 0.006 & $(0.50)$ \\
\hline TOEHOLD & -0.036 & $(-1.38)$ & -0.047 & $(-1.40)$ \\
\hline TENDER & 0.010 & $(1.43)$ & 0.002 & $(0.37)$ \\
\hline TARGET_FEE & -0.018 & $(-0.62)$ & -0.011 & $(-0.38)$ \\
\hline $\mathrm{CASH}$ & $0.038 *$ & $(1.94)$ & $0.044^{*}$ & $(1.76)$ \\
\hline STOCK & $-0.070 * *$ & $(-2.27)$ & $-0.069 * *$ & $(-2.09)$ \\
\hline TRG_HIGHTECH & $-0.016 * *$ & $(-2.00)$ & $-0.019 *$ & $(-1.96)$ \\
\hline TRG_ASSETS & $0.018 * * *$ & $(3.63)$ & $0.019 * * *$ & $(3.93)$ \\
\hline ACQ_ASSETS & $-0.030 * * *$ & $(-6.35)$ & $-0.032 * * *$ & $(-5.82)$ \\
\hline TRG_ROA & 0.004 & $(0.05)$ & -0.010 & $(-0.11)$ \\
\hline ACQ_ROA & -0.033 & $(-0.50)$ & -0.033 & $(-0.51)$ \\
\hline TRG_LEVERAGE & 0.046 & $(0.75)$ & 0.040 & $(0.69)$ \\
\hline ACQ_LEVERAGE & 0.037 & $(0.47)$ & 0.033 & $(0.60)$ \\
\hline TRG_MB & $0.010 *$ & $(1.88)$ & 0.009 & $(1.59)$ \\
\hline ACQ_MB & -0.002 & $(-0.39)$ & -0.002 & $(-0.31)$ \\
\hline LEGOR_UK_ACQ & -0.010 & $(-0.62)$ & -0.008 & $(-0.32)$ \\
\hline LEGOR_UK_TRG & 0.049 & $(1.17)$ & 0.041 & $(0.91)$ \\
\hline CREDITOR_ACQ & $-0.009 * *$ & $(-2.18)$ & $-0.012 * * *$ & $(-4.31)$ \\
\hline CREDITOR_TRG & $-0.018 * * *$ & $(-3.59)$ & -0.006 & $(-0.62)$ \\
\hline GDPPC_ACQ & $0.012 * *$ & $(2.03)$ & $0.021 *$ & $(1.87)$ \\
\hline GDPPC_TRG & 0.012 & $(0.45)$ & 0.021 & $(0.57)$ \\
\hline OBSERVATIONS & 2 & & & \\
\hline R-SQ & 0.4 & & 0.5 & \\
\hline
\end{tabular}


Table 12. Same auditor, acquirer returns and premium

This table shows the results of the regression analysis where the main dependent variable is ACQ_CAR [-5;5]. The sample consists of all completed mergers and acquisitions announced between 2000 and 2014 in which the acquirer owned less than 50\% of the target prior to the purchase and acquired $100 \%$ of the target. All regressions include constant, year and industry dummies. All variables are defined in Appendix 1. ***,**, and * represent 1\%, 5\%, and 10\% significance levels respectively. Standard errors are clustered by year and industry.

\begin{tabular}{|c|c|c|c|c|}
\hline \multirow{2}{*}{$\begin{array}{l}\text { Variable } \\
\text { SAME_AUDITOR }\end{array}$} & \multicolumn{2}{|c|}{ (1) } & \multicolumn{2}{|c|}{ (2) } \\
\hline & $0.021 * * *$ & (6.08) & 0.014* & (1.78) \\
\hline PREMIUM & & & 0.000 & $(0.66)$ \\
\hline SAME_INDUSTRY & -0.003 & $(-0.45)$ & 0.003 & $(0.86)$ \\
\hline TOEHOLD & $-0.024 * *$ & $(-2.14)$ & -0.021 & $(-1.15)$ \\
\hline TENDER & -0.007 & $(-0.63)$ & -0.003 & $(-0.42)$ \\
\hline TARGET_FEE & -0.008 & $(-0.75)$ & -0.002 & $(-0.26)$ \\
\hline CASH & 0.028 & $(1.44)$ & $0.030^{*}$ & $(1.81)$ \\
\hline STOCK & -0.021 & $(-0.76)$ & $-0.034 * *$ & $(-2.14)$ \\
\hline TRG_HIGHTECH & 0.005 & $(0.46)$ & 0.002 & $(0.17)$ \\
\hline TRG_ASSETS & -0.004 & $(-0.89)$ & -0.003 & $(-0.59)$ \\
\hline ACQ_ASSETS & $-0.012 * *$ & $(-2.14)$ & $-0.007 *$ & $(-1.99)$ \\
\hline TRG_ROA & 0.028 & $(0.78)$ & -0.024 & (.) \\
\hline ACQ_ROA & $0.122 * * *$ & $(2.92)$ & $0.086 * *$ & $(2.02)$ \\
\hline TRG_LEVERAGE & 0.062 & $(1.50)$ & 0.046 & $(1.35)$ \\
\hline ACQ_LEVERAGE & $0.087 * *$ & $(2.02)$ & $0.067 *$ & $(1.95)$ \\
\hline TRG_MB & 0.007 & $(1.05)$ & -0.000 & $(-0.12)$ \\
\hline ACQ_MB & 0.003 & $(0.62)$ & $-0.003 * *$ & $(-2.17)$ \\
\hline LEGOR_UK_ACQ & $-0.020 * * *$ & $(-2.80)$ & $-0.016 * *$ & $(-2.02)$ \\
\hline LEGOR_UK_TRG & 0.011 & (.) & -0.001 & $(-0.12)$ \\
\hline CREDITOR_ACQ & -0.003 & $(-0.91)$ & -0.001 & $(-0.34)$ \\
\hline CREDITOR_TRG & -0.004 & $(-0.62)$ & 0.002 & $(0.48)$ \\
\hline GDPPC_ACQ & $0.008 * *$ & $(2.44)$ & 0.009 & $(1.34)$ \\
\hline GDPPC_TRG & $-0.026 * *$ & $(-2.33)$ & -0.009 & $(-0.72)$ \\
\hline OBSERVATIONS & \multirow{2}{*}{\multicolumn{2}{|c|}{$\begin{array}{r}351 \\
0.309\end{array}$}} & \multicolumn{2}{|c|}{316} \\
\hline R-SQ & & & 0.2 & \\
\hline
\end{tabular}

